\title{
Experimental Investigation of Square Filled Steel Multi-Cell Column
}

\author{
Ahmed Wafa ${ }^{1}$, Maher Elabd ${ }^{2}$, Kamel Kandil ${ }^{3}$ \\ 1 Teaching Assistant. Civil Eng. Dept. Faculty of Eng. ‘ Kafr El-Sheikh University, Egypt. \\ 2 Lecturer, Civil Eng. Dept., Faculty of Eng., Menoufia University, Egypt. \\ 3 Professor of Steel Structures, Civil Eng. Dept. ‘ Faculty of Eng., Menoufia University, Egypt. \\ (Corresponding author: ahmedwafa1000@gmail.com)
}

\begin{abstract}
Multi-Cell Steel Column (MCC) presents an innovative solution for the problem of local buckling in thin walls of steel column of box section type. This study presents an extension for this innovative solution by filling the column cells with normal concrete capable of enhancing the axial load capacity of such columns. A group of eight MCSC specimens of square cross-section were experimentally tested by applying axial compression load which included hollow and those filled with concrete. In addition, numerical analysis was carried out using ABAQUS, Finite Element (FE) software, in order to validate the experimental results. A parametric study was conducted in this investigation to include more parameters such as number of internal cells wall external to internal wall thickness. Numerical results showed a good agreement with the experimental results. Both experimental and numerical results showed great enhancement in the load carrying capacity of composite (MCC) compared to non-composite ones that ranged between $690 \%$ and $800 \%$. In addition, there was an increase between (MCC) and Single Cell Steel Column (SCC) that ranged between $18 \%$ to $27 \%$ increase of. A remarkable improvement in the ductility behaviour was also observed during the study.
\end{abstract}

Keywords: SCC, MCC, Composite, Steel, Columns.

\section{Introduction}

Hollow Core Steel Tube columns have become an important structural element in most of recent steel structures. This type of columns includes only one cell and hence they are termed Single-Cell Column (SCC). Local buckling of the shell of hollow core steel columns elements is a crucial problem that may control the behaviour and the capacity of such columns. A smart solution for this problem was introduced by using internal continuous stiffeners so as to reduce the tendency for local buckling of the outer shell to occur. These internal stiffeners divided the column into many small columns called cells and the column is then termed a Multi-Cell Column (MCC). Figs. 1, 2 Presents different suggestions for possible cross sections for MCC .

The behaviour of such columns was first introduced by Królak, et al (2007) and Królak, et al (2009). Dividing the column internally into cells has led to the increase of the load carrying capacity of such columns besides enhancements brought to the buckling behaviour, see Fig. 2. Prior studies in this field were limited only to investigate the behaviour of such columns to axially loaded MCC. In general engineering practice, the proposed MCC are planned to be used in heavy construction projects such as bridge piers, high rise buildings, offshore platforms

... etc. For such structures, axial loads are of high concern due to the probability of overloading, impact loads, road accidents or even to meet the requirements of different bridge design codes.

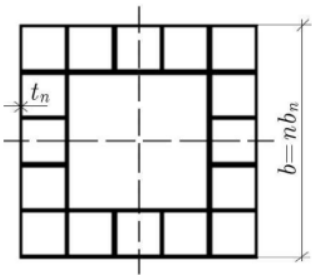

a)

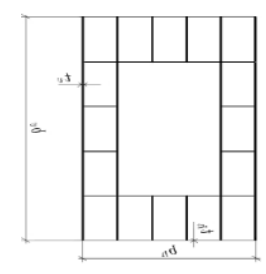

section b) MCC of rectangular cross section

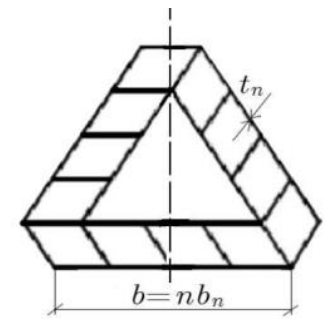

d) MCC of Triangular

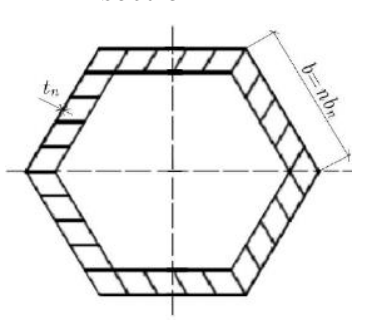

e) Hexagonal
Fig.1. Multi-Cell Columns with different cross sections 


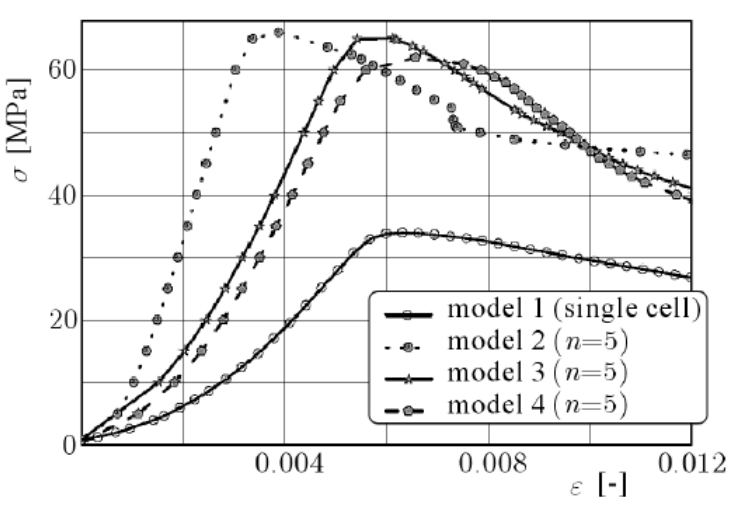

Fig.2. Stress-Strain behavior for MCC with different cross sections

In this study, a comprehensive experimental program is aimed to investigate the behavior and strength of concrete-filled multi cell columns. The presented tests are conducted under static loading to determine the load-axial shortening, behavior, load-axial strain behavior of the external steel shell, composite column strength and failure mode of the composite columns. Test parameters include different concrete strength. Tensile tests for steel sheet material are also conducted on steel sheets used on multi-cell columns to determine the actual stress-strain behavior of the steel shell. Standard compression tests are conducted on concrete cubes at different ages until the design strength is reached and at the time of testing. The tests provide the required data regarding the concretefilled-multi-cell composite columns. By the end of the test program, test results are compared against design capacities predicted using current codes of practice of composite columns.

\section{Experimental Program and Test Setup} 2.1 Experimental test program description

A total of eight specimens of columns were prepared using square cross-section, that is:

- Two specimens of hollow thin-walled column with single-cell square cross-section (SCC)،

- Two specimens of hollow thin-walled Multi-cell columns with square cross-section (MCC)،

- Two specimens of a thin-walled composite column with single-cell square cross-section with normal concrete (SCCC)،

- Two specimens of thin-walled Multi-cell composite columns with square cross-section with normal concrete (MCCC) .

The (SCC) was made of one piece of 90 degree bent steel sheet to form a full square section. The fourth corner of the section was formed by connecting the ends of the sheet using spot welding. The total height of all specimens was $250 \mathrm{~mm}$ due to the limitations of compression test machine. The material properties of the steel (determined experimentally) were as follows: Young's modulus $\mathrm{E}=210 \mathrm{GPa}$, Poisson's ratio $\mathrm{n}=0.3$, yield stress $\mathrm{Fy}=360 \mathrm{MPa}$ and ultimate strength $\mathrm{Fu}=520 \mathrm{MPa}$. The ratio of the wall widthto-thickness was b1/t $1=100$.

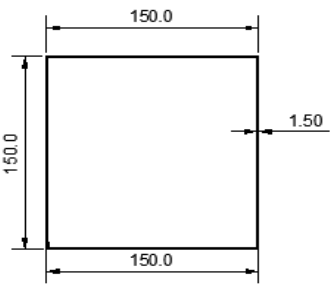

PLAN

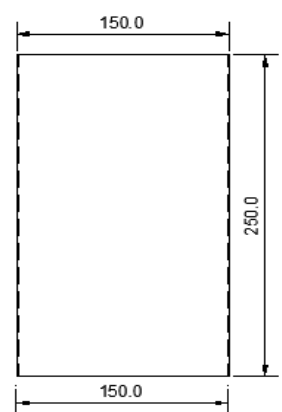

ELEVATION
Fig.3. Details of Single-Cell Column Section (SCC)

The (MCC) was made of the same section described above but the steel sheet was $1.0 \mathrm{~mm}$ thickness instead of 1.50 for the SCC. The internal stiffeners/separators were made as I-shape profiles of $1.0 \mathrm{~mm}$ thickness as the external shell. The crosssection of this specimen and its dimensions are presented in Fig. 4.

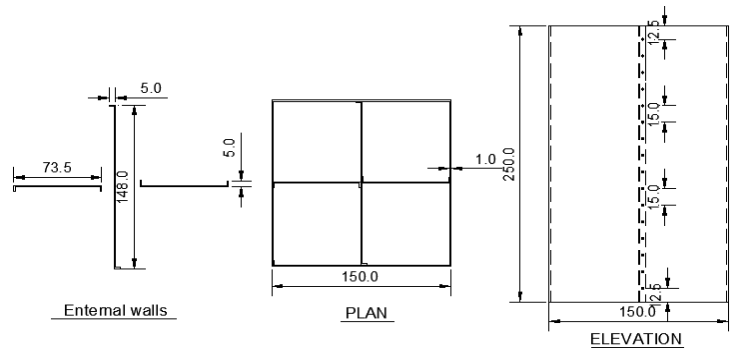

Fig.4. Details of Multi-Cell Column Section (MCC).
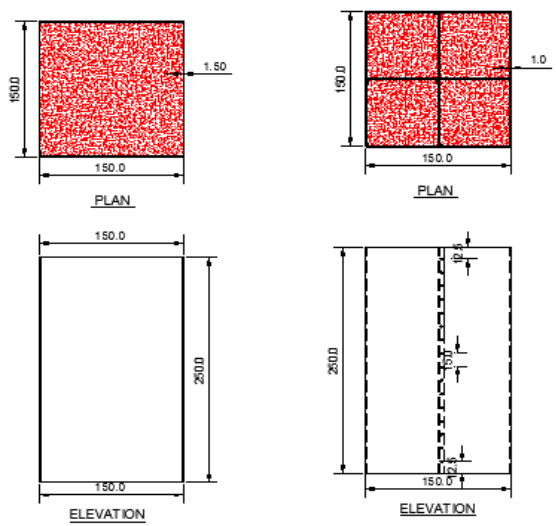

Single-cell composite column (SCCC)

Multi-cell composite column (MCCC)

Fig.5. Dimensions of Composite SCCC and MCCC 
The four specimens of composite SCCC and MCCC were having the same dimensions of non-composite specimens mentioned above. Composite steel columns were filled with fresh normal concrete of the same mix. The cross-section of this specimen is presented in Fig. 5.

Table 1: Properties and details of specimens

\begin{tabular}{|c|c|c|c|c|c|c|c|}
\hline \multirow{2}{*}{$\begin{array}{c}\text { Specim } \\
\text { en }\end{array}$} & \multicolumn{3}{|c|}{ imensionsD } & $\begin{array}{c}\text { Area } \\
\text { of } \\
\text { Steel } \\
\mathrm{A}_{\mathrm{s}} \\
\mathrm{mm}^{2}\end{array}$ & $\begin{array}{c}\text { Area } \\
\text { of } \\
\text { Con. } \\
\mathrm{A}_{\mathrm{c}} \\
\mathrm{mm}^{2}\end{array}$ & $\begin{array}{c}\text { Total } \\
\text { Area } \\
{ }_{\mathrm{t}} \mathrm{A} \\
\mathrm{mm}\end{array}$ & $\begin{array}{c}\text { No. } \\
\text { of } \\
\text { cells }\end{array}$ \\
\cline { 2 - 9 } & $\begin{array}{c}\mathrm{B} \\
\mathrm{mm}\end{array}$ & $\begin{array}{c}\mathrm{t} \\
\mathrm{mm}\end{array}$ & $\begin{array}{c}\mathrm{L} \\
\mathrm{mm}\end{array}$ & & & & \\
\hline SCC & 150 & 1.50 & 250 & 891 & 0 & 22500 & one \\
\hline MCC & 150 & 1.50 & 250 & 915 & 0 & 22500 & four \\
\hline SCCC & 150 & 1.00 & 250 & 891 & 21609 & 22500 & one \\
\hline MCCC & 150 & 1.00 & 250 & 915 & 21585 & 22500 & four \\
\hline
\end{tabular}

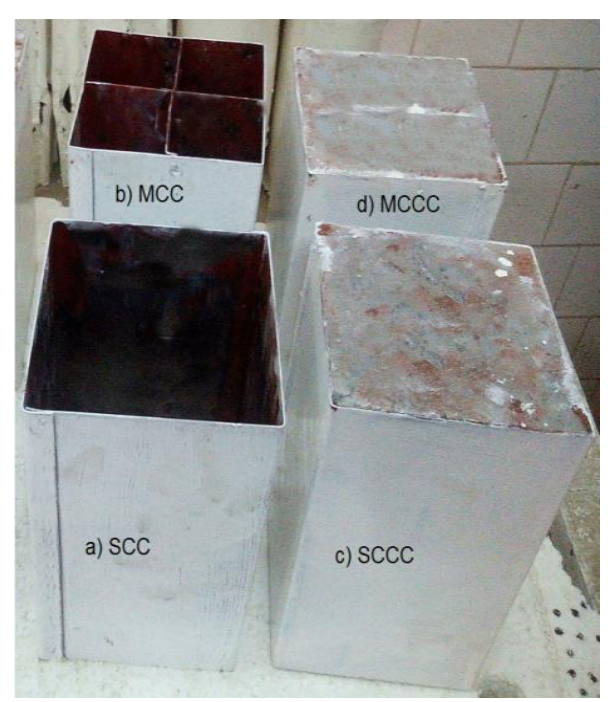
a) $\mathrm{SCC}$
b) $\mathrm{MCC}$
c) SCCC
d) $\mathrm{MCCC}$

Fig.6. Photos of specimens

\subsection{Preparation of concrete}

The mix design of normal-weight concrete used in this study in filling the specimens is shown in Table (2). The average density of the normal-weight mix was $23.45 \mathrm{kN} / \mathrm{m}^{3}$. The strength of crushing standard cubes after 7 and 28 days of the cast date were 25.9 and $32.3 \mathrm{MPa}$; respectively. The average compressive strength $\left(\mathrm{f}_{\mathrm{cu}}\right)$ of concrete of $32.3 \mathrm{MPa}$.

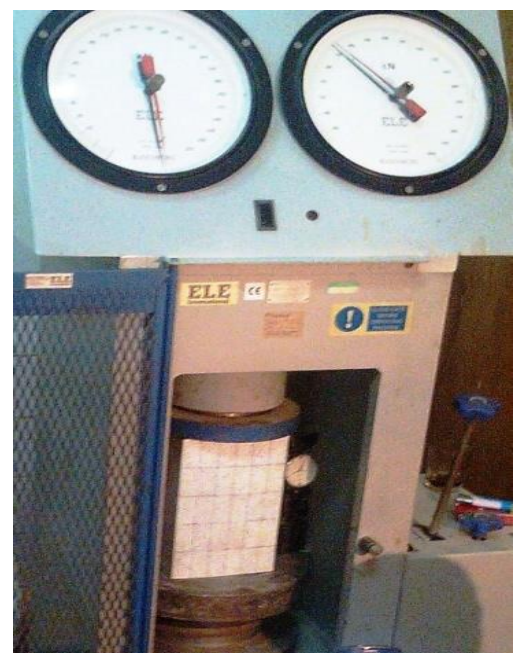

Fig.7. Test setup of specimen

Table 2: The normal-weight mix

\begin{tabular}{|c|c|c|c|c|}
\hline $\begin{array}{c}\text { Admixture } \\
\text { content } \\
(\mathrm{kN})\end{array}$ & $\begin{array}{c}\text { Water } \\
\text { content } \\
(\mathrm{kN})\end{array}$ & $\begin{array}{c}\text { Sand } \\
\text { content } \\
(\mathrm{kN})\end{array}$ & $\begin{array}{c}\text { Coarse } \\
\text { Aggregate } \\
\text { content } \\
(\mathrm{kN})\end{array}$ & $\begin{array}{c}\text { Cement } \\
\text { content } \\
(\mathrm{kN})\end{array}$ \\
\hline 0.054 & 1.863 & 8.090 & 8.090 & 5.394 \\
\hline
\end{tabular}

\subsection{Test setup and instrumentation}

The tests in this study were carried out in the laboratory of Menoufia University Faculty of Engineering using a compression machine of 2000 $\mathrm{kN}$ Capacity. The specimens were prepared in the testing machine as shown in figure 7. A dial gauge was used to measure the axial displacement of the top head of the testing machine and was fixed parallel to the specimen axis.

\subsection{Test procedures}

The load was applied to the specimens in the form of axial uniform compression over the concrete and steel tube. The load was applied in a slow rate to avoid any high strain rates effects. The dial gauge and load readings were checked carefully recorded while loading was being applied to the specimens within the elastic limit. The load was applied at $10 \mathrm{kN}$ intervals in order to have sufficient data points to delineate load-displacement curves after the immediate drop of the load due to local buckling, the test continued as the load stabilized until the load started again to increase slightly when the testing ended. Then the specimen was removed and carefully examined after the test. 


\section{Experimental Results:}

The axial load against axial displacement curves of specimens was drawn to discuss their behavior. Comparisons between load capacities of specimens are presented. Ratios of increase in load capacity of columns due to increasing no of cell and filled with normal concrete are compared with one cell specimen. The experimental load capacity of specimens and cross section area of specimens are shown in Table 3. The experimental loaddisplacement curves for all specimens are shown in figures 8 to 11 .

Table 3: The experimental load capacity of specimens.

\begin{tabular}{|c|c|c|c|c|c|c|}
\hline $\begin{array}{l}3 \\
\frac{3}{2} \\
0 \\
0\end{array}$ & 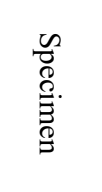 & $\begin{array}{l}. \text { Con } \\
\mathrm{cu} f \\
\mathrm{MPa}\end{array}$ & $\begin{array}{c}\text { Stee } \\
1 \\
{ }_{\mathrm{y}} \mathrm{f} \\
\mathrm{MPa}\end{array}$ & $\begin{array}{c}\text { Area } \\
\text { of } \\
\text { steel } \\
\mathrm{A}_{\mathrm{s}} \\
\mathrm{mm}^{2}\end{array}$ & $\begin{array}{l}\text { Test } \mathrm{P} \\
\mathrm{kN}\end{array}$ & $\begin{array}{l}\text { Ratio of } \\
\text { increase } \\
\text { to } \\
\text { SCC } \%\end{array}$ \\
\hline \multirow{2}{*}{$\begin{array}{l}\text { Non- } \\
\text { Comp. }\end{array}$} & SCC & - & 360 & 891 & 90 & 0.00 \\
\hline & $\mathrm{MCC}$ & - & 360 & 915 & 114 & 26.67 \\
\hline \multirow{2}{*}{$\begin{array}{l}\text { Conc. } \\
\text { Filled } \\
\text { Tube }\end{array}$} & SCCC & 32.3 & 360 & 891 & 620 & 690.00 \\
\hline & $\mathrm{MCCC}$ & 32.3 & 360 & 915 & 730 & 812.00 \\
\hline
\end{tabular}

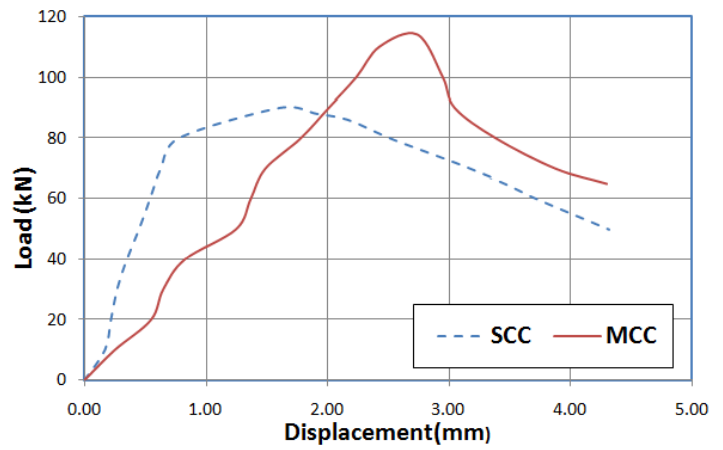

Fig.8. Experimental load-displacement curves for SCC and MCC.

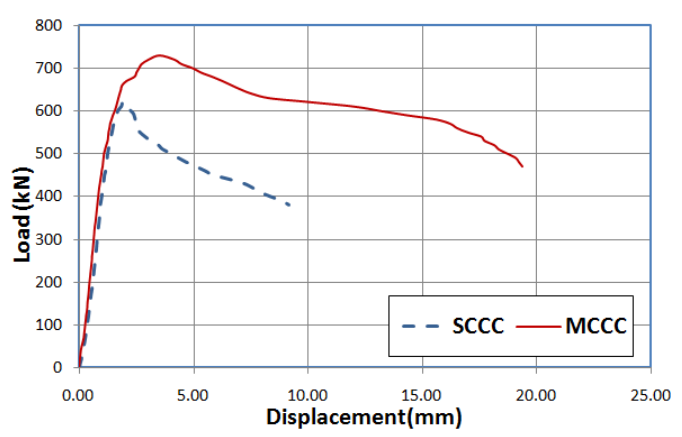

Fig.9. Experimental load-displacement curves for SCCC and MCCC.
Comparisons between load carrying capacity of specimens SCC and MCC are shown in Fig.8. It can be noted that the load capacity of column increased due to using multi-cell (4-cells) section. This increase ranged between $26 \%$ up to $27 \%$ as shown in Fig. 8 .

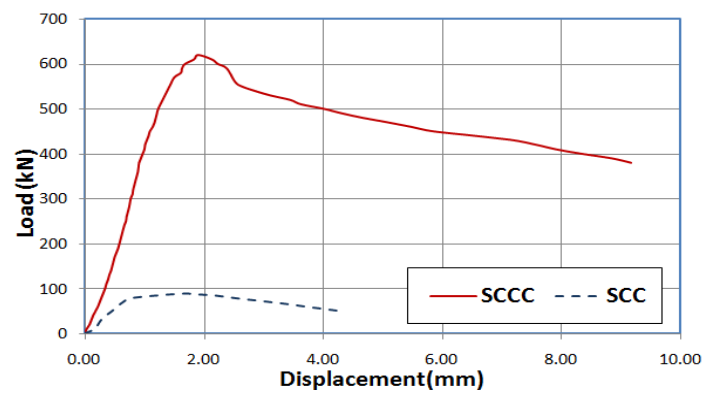

Fig.10. Experimental load-displacement curves for SCC and SCCC.

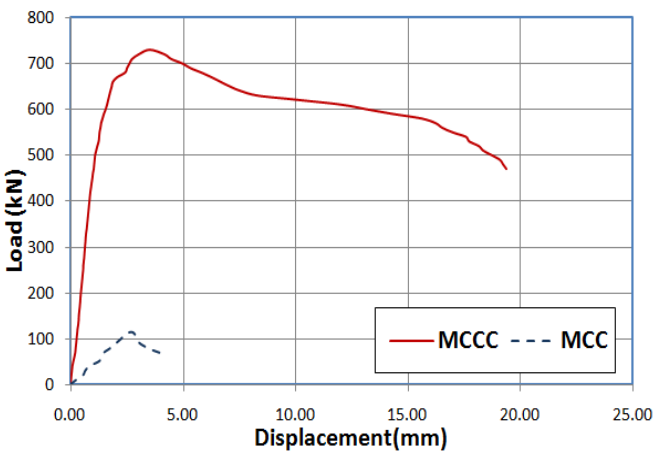

Fig.11. Experimental load-displacement curves for $\mathrm{MCC}$ and MCCC.

For composite columns SCCC and MCCC, it can be seen that there was an increase of load carrying capacity of those types due to the use of plain concrete to fill the columns Figure 9. This increase was around $18 \%$ for MCCC. Comparing between SCC and SCCC, a dramatic increase of $690 \%$ was noticed as seen in figure 10. However, the increase between MCC and MCCC was only 640\% figure 11. 

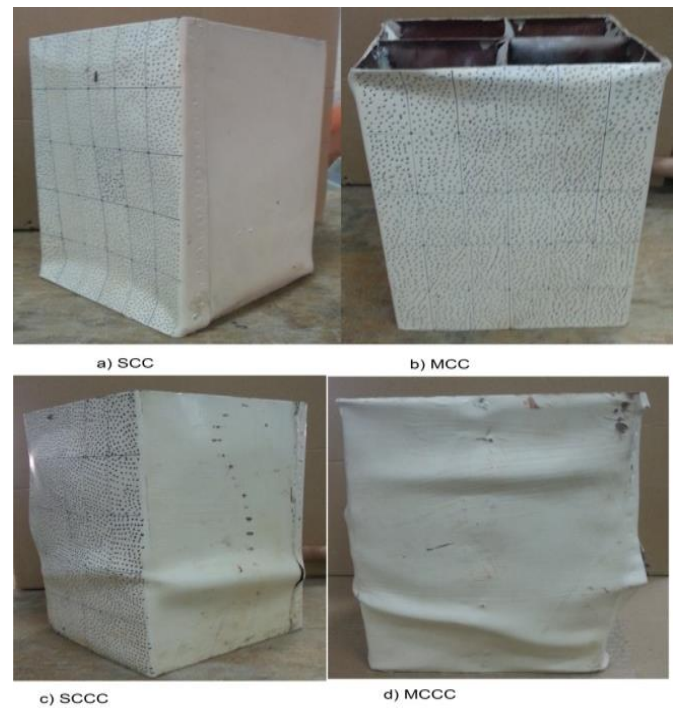
a) $\mathrm{SCC}$
b) MCC
c) SCCC
d) $\mathrm{MCCC}$

Fig.12. Experimental failure mode and deformation shape at failure

\section{Conclusions}

The current study presented an experimental investigation of using longitudinal internal column stiffeners dividing the square column section into cells. Tests on hollow and concrete-filled square columns which were concentrically loaded were carried out. The overall width-to-plate thickness ratio of the tube sections were 100 for single cell sections (SCC) and 150for multi-cell column (MCC). Plain concrete of $32.3 \mathrm{MPa}$ was used to fill both types of the above-mentioned sections and to be called (SCCC) for single cell and (MCCC) for multi-cell columns, respectively. The column strengths, loadaxial strain relationships and failure modes of the columns have been reported.

The following conclusions can be summarized from the current study :

1.There was an increase between (MCC) and Single Cell Steel Column (SCC) that ranged between 18\% to $27 \%$ increase.

2.In case of MCCC, the load carrying capacity of composite multi-cell column (MCCC) ranged between $690 \%$ and $800 \%$ compared to noncomposite ones (MCC).

\section{References}

[1] Królak, M., Kowal-Michalska, K., Mania, R., \&Swiniarski, J. (2007), "Experimental tests of stability and load carrying capacity of compressed thin-walled multi-cell columns of triangular cross-section", Thin-Walled Structures, 45(10), 883-887.

[2] Królak, M., Kowal-Michalska, K., Mania, R. J.,
\&Świniarski, J. (2009), "Stability and load carrying capacity of multi-cell thin-walled columns of rectangular cross-sections". Journal of Theoretical and Applied Mechanics, 47(1), 435456.

[3] Chen W., Wierzbicki T., 2001, "Relativements of single cell, multi-cell and foam-filled thin-walled structures in energy absorption", Thin-Walled Structures,39, 287-306.

[4] Grądzki R., Kowal-Michalska K., 1985, "Elastic and elasto-platic buckling of thin-walled columns subjected to uniform compression", Thin-Walled Structures Journal, 3, 93-108.

[5] Kim H.S., 2002, "New extruded multi-cell aluminum profile for maximum crash energy and weight efficiency", Thin-Walled Structures, 40, 311-328.

[6] Kołakowski Z., Kowal-Michalska K., 1999, "Selected Problems of Instability in Composite Structures", Technical University of Lodz, Lodz, Poland.

[7] Królak M., Kowal-Michalska K., 2004a, "Stability and load-carrying capacity of multi-cell columns subjected to compression", Proc. of IV Coupled Instabilities in Metal Structures, CIMS 2004, Pignatario M. (Edit.), Rome, 213-222.

[8] Królak M., Kowal-Michalska K., 2004b, "Stability and ultimate load of multi-cell orthotropic columns subjected to compression", Proc. of the 8-th SSTA Conference, Jurata, Poland, 235-239.

\section{NOMENCLATURE}

B Width of cross-section

L Length of column specimen

$t$ Plate Thickness of stainless-steel plate

$b_{s}$ Width of the internal wall

$h_{s}$ Height of the internal wall

$\mathrm{A}_{\mathrm{c}}$ Cross-sectional area of concrete

$\mathrm{A}_{\mathrm{s}}$ Cross-sectional area of steel specimen

$f_{y}$ Yield stress of steel tube

$\mathrm{f}_{\mathrm{cu}}$ Unconfined compressive cube strength of concrete

$f_{c}$ Unconfined compressive cylinder strength of concrete

$\mathrm{f}_{\mathrm{cc}}$ Confined compressive strength of concrete

$\mathrm{f}_{1} \quad$ Lateral confining pressure

E Young's modulus

$\varepsilon_{c}$ Unconfined concrete strain

$\varepsilon_{\mathrm{cc}}$ Confined concrete strain

$\mathrm{P}_{\text {Test }}$ Test Ultimate load (test load) 